\title{
"We Hold It in Trust": Global Wildlife Conservation, Africanization, and the End of Empire
}

\section{Jeff Schaner}

\begin{abstract}
In the early 1960s, the College of African Wildlife Management opened in northern Tanzania. The institution was designed to lessen the impact of decolonization by training the first generation of African wildlife wardens in the tradition of their European predecessors. The product of racialized narratives about African violence and the growth of international conservation organizations, the college could be understood as a straightforward neocolonial institution designed to perpetuate British and western influence over land and animals in East Africa. In contrast, this paper pays close attention to the circumstances and context of the college's founding, the debates over funding and control, and its institutional culture. These aspects all suggest that African governments sought to use the college as a vehicle for pursuing the Africanization of the civil service and for formalizing a contractual relationship with international organizations about mutual obligations not only to Tanzania's wildlife sector but also the country's political economy. This focus on a conservation institution created in the early days of independence demonstrates that the work of decolonization continued after independence, and that expatriate personnel and culture remained embedded in new nations, informing our narratives of decolonization, conservation, and nationalism.
\end{abstract}

\section{INTRODUCTION}

The birth of the College of African Wildlife Management at Mweka, Tanzania, in 1963 represented an exciting development not only for global conservationists interested in African wildlife but also for the leadership and citizenry of newly independent nations. ${ }^{1}$ The college was designed to train a new generation of African conservationists to replace Europeans leaving Africa with the end of colonial rule. Housed in Tanzania, it was envisioned as an institution to serve the entire continent. An attendee at the college's opening ceremony described how, "as if to mark the occasion the normal cloud blanket had lifted from Kilimanjaro, and the gleaming, sun-lit face of Kibo, the ice and snow of its glaciers sparkling like a birthday cake, looked

Jeff Schauer is an assistant professor of history at the University of Nevada, Las Vegas. He thanks Richard Ambani and Peterson Kithuka at the Kenya National Archives for sharing their expertise and knowledge of the archive, and Peter Hoffenberg, Susan Pennybacker, and Michelle Tusan for comments on a conference version of this article. He is also grateful to the editors of the Journal of British Studies and several anonymous reviewers for the significant labor that their careful critiques involved.

${ }^{1}$ As a colony and then as a new nation state formed in1961, the East African territory in question was known as Tanganyika. In 1964, Tanganyika united with Zanzibar and became Tanzania. For the sake of simplicity and consistency, I refer throughout to the colony and state as Tanzania, except where it is appears in a quoted source as Tanganyika. 
down happily on the scene."2 The new college's motto, "We Hold It in Trust," alluded to the idea that wildlife was held in trust for a broader humanity because of its global significance, a point of pride and profit for the leadership of new African states and a reassurance to concerned conservationists. Kenya's Daily Nation newspaper, reporting on the new training school, observed that "the Tanganyika government means business over game preservation, and is spending three times as much on it per annum as was spent under British rule ... a pretty good refutation of the moans of alleged wildlife experts that when an African government comes into power game will be slaughtered."3 A 1964 story in the Manchester Evening News reported that "on the cool slopes below towering Mt Kilimanjaro, nineteen Africans are learning to conserve the wild animals which their tribal brothers still hunt for food and ivory." 4 As the starkly different newspaper accounts suggest, this story was more complex than the sun-bathed ceremony in the shadow of Mt. Kilimanjaro let on. The college was held up on the one hand as an example of the industrious and committed nature of new African states and on the other as proof that international conservationists could wield clout in independent Africa. It was interpreted as both a marker of nationalism's vigor and an antidote to Africa's supposedly historic cultural deficiency.

Conservation initiatives in post-independence Africa are often described in one of two fashions. In some cases, building on scholarship about the relationship between colonialism, development, land, and resources, scholars describe these initiatives as representing the legacy of imperialism. ${ }^{5}$ That is, they reflect totalizing European ideas about African landscapes, the violence of the colonial boundary-drawing that established national parks, the persistence of colonial institutions, or pernicious new ways through which neocolonial actors continued to dominate wildlife policy making in Africa. ${ }^{6}$ In other cases, scholarship focuses on the initiative and agency of new African states, in partnership with or independent from the machinations of global conservationists. ${ }^{7}$ Existing work on the College of African Wildlife

\footnotetext{
${ }^{2}$ Bruce Kinloch, Tales from a Crowded Life (Moray, 2008), 283.

3 "No Time for This Holier-Than-Thou Attitude," Daily Nation, 28 July 1963, KW 20/15, 1963, Kenya National Archives (hereafter KNA).

${ }^{4}$ Dennis Neeld, "Safari College' Leads Bid to Conserve Wildlife," Manchester Evening News, 29 October 1964, KW 20/16, 1963-1965, KNA.

${ }^{5}$ On that legacy, see John MacKenzie, Empire of Nature: Hunting, Conservation and British Imperialism (New York, 1988); William Beinart and Lotte Hughes, Environment and Empire (Oxford, 2007); William Adams, Against Extinction: The Story of Conservation (Sterling, VA, 2004); Edward Steinhart, Black Poachers, White Hunters: A Social History of Hunting in Colonial Kenya (Athens, OH, 2006); Jan Bender Shetler, Imagining Serengeti: A History of Landscape Memory in Tanzania from Earliest Time to the Present (Athens, $\mathrm{OH}, 2007)$; Helen Tilley, Africa as a Living Laboratory: Empire, Development, and the Problem of Scientific Knowledge, 1870-1950 (Chicago, 2011); Joseph Morgan Hodge, Triumph of the Expert: Agrarian Doctrines of Development and the Legacies of British Colonialism (Athens, $\mathrm{OH}, 2007$ ); and Christopher A. Conte, Highland Sanctuary: Environmental History in Tanzania's Usambara Mountains (Athens, OH, 2004).

${ }^{6}$ Dan Brockington, Fortress Conservation: The Preservation of the Mkomazi Game Reserve, Tanzania (Athens, OH, 2002); Melissa Leach and Robin Mearns, eds., The Lie of the Land: Challenging Received Wisdom on the African Environment (Oxford, 1996); and Roderick Neumann, Imposing Wilderness: Struggles over Livelihood and Nature Preservation in Africa (Berkeley, 2002).

${ }^{7}$ For important examples, see Julie M. Weiskopf, "Socialism on Safari: Wildlife and Nation-building in Postcolonial Tanzania, 1961-77," Journal of African History 56 (2015): 429-47; and Elizabeth Garland, "The Elephant in the Room: Confronting the Colonial Character of Wildlife Conservation in Africa," African Studies Review 51, no. 3 (December 2008): 51-74.
} 
Management (CAWM) explores its role as a site for understanding the "professional lives" of people laboring in a wildlife sector shaped by mutually reinforcing colonial and capitalist relationships and forces in the context of Tanzania's national and global trajectories. ${ }^{8}$ My account of the creation of the college instead attends to the relationship between decolonization and conservation. I argue that rather than culminating in "flag independence," decolonization represented fluid and ongoing endeavors, maneuvers over "semblances of sovereignty" analogous to "the imperfect tense [that] describes an indefinite ending ... a messy, contingent and contested constellation of intersecting and often competing processes, which cut across local, national, imperial, and global contexts." 10 Like other work on conservation in particular and the post-independence period more broadly, this article seeks to account for not only the continuities that have preoccupied much scholarship on conservation in Africa but to explore how those were "counterbalanced by rupture and dynamism"11 and, crucially in this case, institutional entanglement. In short, I aim to reconcile Africanists' emphasis on neocolonial continuities with imperial historians' preoccupations with change. Novel institutions that bridge period and place provide important sites for such study that are less constrained by the needs to demonstrate the finality of decolonization or its failure.

This article's arc is narrative, tracing the creation of the college and the attachment of external interests to its structure and activities. The college was the product of competing and interlocking processes and agendas. The racially tinged fears of many European conservationists about the future of wildlife in independent Africa informed many of the efforts by imperial-turned-global conservationists to retain control over policy making in Africa. Their rhetoric informed official British thinking about Africanization. This combination of interests made the college a vehicle for the idea of trusteeship so central to imperialism writ large and colonial conservation in particular. The intermingling of global and imperial interests was, in turn, made possible by the "postwar conservation boom," a proliferation of global and international conservation institutions. ${ }^{12}$ Yet a different set of interests also shaped the college. The Tanzanian state's commitment to the development of its tourism and wildlife sectors, and its determination to assert greater sovereignty over these sectors, corresponded with its British-influenced policy of Africanization, the replacement of European government personnel with Tanzanians. To make the college part of these nationalization processes, the Tanzanian government, which was ultimately responsible for

\footnotetext{
${ }^{8}$ Elizabeth Garland, "State of Nature: Colonial Power, Neoliberal Capital, and Wildlife Management in Tanzania" (PhD diss., University of Chicago, 2006), 33.

${ }^{9}$ Ann Laura Stoler, Duress: Imperial Durabilities in our Times (Durham, 2016), 195.

${ }^{10}$ Andrew W. M. Smith and Chris Jeppesen, "Development, Contingency and Entanglement: Decolonization in the Conditional," in Britain, France and the Decolonization of Africa: Future Imperfect?, ed. Smith and Jeppesen (London, 2017), 1-14, at 1, 4. See also, Martin Thomas, Bob Moore, and L. J. Butler, Crises of Empire: Decolonization and Europe's Imperial States (New York, 2015); W. O. Maloba, The Anatomy of Neo-Colonialism in Kenya: British Imperialism and Kenyatta, 1963-1978 (Cham, 2017. In contrast, earlier scholarship on decolonization which emphasized the metropolitan-oriented "why" of decolonization rather than the "how." See for example, John Darwin, The End of the British Empire: The Historical Debate (Oxford, 1991).

${ }^{11}$ Weiskopf, "Socialism on Safari," 429.

12 Roderick P. Neumann, "The Postwar Conservation Boom in British Colonial Africa," Environmental History 7, no. 1 (January 2002): 22-47.
} 
creating and monitoring the college, leveraged funders from a range of global and regional sources. The day-to-day operations and curriculum of the institution that resulted from these collective efforts were informed by a greater emphasis on scientific expertise than they were during the colonial era, but continued to emphasize a broad range of field and animal control experiences. Organizational shape, finances, and personnel decisions all proved sites of contestation and controversy during the 1960s and 1970s, and examining some of the most heated debates between students and college leadership provides concrete examples of colonial continuities in methods and attitudes. The college sat at the foot of Kilimanjaro, but above all it was located at the juncture of global, local, and imperial events. Global developments like the surge in conservation work provided some impetus and support for the college as it emerged. National developments like the push for Africanization and the politics of post-independence leadership offered further opportunities for creative conservation work, and constraints on how far that work could openly replicate colonial relationships and structures. The British government's involvement in structuring and funding Africanization, together with the compatibility of expatriates' continued presence with Tanzania's Africanization metrics, all represent strong imperial influences. The college's creation illustrates the contested coloniality of the conservation world, but it also represents an opportunity for historians to think about how the "afterlives of empire"-consisting "not only of individual people, but also of the ideas and institutions that were forged in imperial days and outlived the regimes under which they were born"-were negotiated into the fibers of new states and the relationships that persisted with the former imperial power. ${ }^{13}$

\section{GLOBAL CONSERVATION AFTER WORLD WAR II}

A critical factor in explaining the creation of the College of African Wildlife Management was the "postwar conservation boom," stemming from Britain's postwar development projects, the rise of expertise in the wildlife sector, the growth of global tourism, and international conservation organizations. ${ }^{14}$ The novelty of the postwar boom, defined by the proliferation of global conservation organizations and conservation expertise more broadly, is questionable, and local initiatives also played a key role in shaping conservation agendas. ${ }^{15}$ But more striking is the absence of decolonization from traditional explanations for the rise in international interest in African wildlife. Global conservation efforts in East Africa in particular were framed by the uncertain chronology of decolonization and by the violence at the end of empire in Congo and Kenya.

${ }^{13}$ Jordanna Bailkin, The Afterlife of Empire (Berkeley, 2012), 1.

${ }^{14}$ Neumann, "The Postwar Conservation Boom in British Colonial Africa," 23.

15 T. Vaughan-Jones, note on formation of Game Department, 1934 to 1948, 4 August 1939, SEC 1/ 993, National Archives of Zambia (hereafter NAZ). Contemporary accounts and more regional scholarship alike suggest the "boom" might have begun earlier than Neumann (2002) suggests. Charles R. S. Pitman, A Report of a Faunal Survey of Northern Rhodesia, with Especial Reference to Game, Elephant Control and National Parks (Livingstone, 1934); Ruben Matheka, "Antecedents to the Community Wildlife Conservation Programme in Kenya, 1946-1964," Environment and History 11, no. 3 (August 2005): 239-67. 
The postwar world saw a steady growth in the number of organizations taking an interest in wildlife, in the decolonizing world in general and in Africa in particular. UNESCO was created in 1945, the International Union for the Conservation of Nature in 1948, the Nature Conservancy in 1951, and the World Wildlife Fund in 1961. These organizations swiftly came to exercise more influence than did older, imperial preservation groups like the Society for the Preservation of the Fauna of the Empire (1903). Alongside these global mainstays of the conservation movement and the funds and projects they generated, a host of specialized, park-specific, and regional organizations sprang up. These ranged from the Serengeti Research Institute (Tanzania, 1962) and the Tsavo Project (Kenya, 1966), to the Nuffield Unit for Tropical Animal Ecology (Uganda, 1961) and the East African Wildlife Society (East Africa, 1961). ${ }^{16}$ These conservation-oriented organizations were part of a rapid growth in global and international civil society in response to the violence of the Second World War, the onset of decolonization, the Cold War, new philosophies of development and international relations, and the growth of the United Nations and its branches. Conservation became connected to the work of the Ford Foundation (1963), the International Bank for Reconstruction and Development (1944), and the United Nations Food and Agriculture Organization (1945) because of the funding, expertise, and languages of development that these bodies helped to generate, popularize, and standardize. ${ }^{17}$

Many of these organizations were animated by optimism about the capacity of transnational institutions to reshape a battered world for the better. But that optimism was combined with urgency and tempered by anxiety about what crises of food and population would mean for the planet. ${ }^{18}$ And in the realm of conservation, fear played a prominent role in the thinking and organization of postwar conservationists when they looked at Africa. The rise of nationalist parties, the weakening of imperial power, and the decolonization of territories in Asia and later in West Africa suggested that European rule, along with the patronage (however tepid) it offered conservationists, was waning. Many conservationists assumed that decolonization in Africa would lead to the destruction of the continent's wildlife populations. Apocalyptic language came to dominate their thinking and rhetoric. Two prominent advocates of wildlife preservation described in characteristically dramatic language how independence would lead to "absolute chaos ... Commercial poaching and organized hunting will quickly wipe out all game outside stipulated sanctuaries ... the game within [reserves will be] destroyed in a mad rush for political loot and a carve-up of all Kenya's land." 19 Another invoked the "losing battle" to save wildlife

\footnotetext{
${ }^{16}$ This latter organization had been preceded by Kenya and Tanzania Wild Life Societies, both created in 1956.

${ }^{17}$ For influential work on this new community of global organizations and their experts, see Akira Iriye, Global Community: The Role of International Organizations in the Making of the Contemporary World (Berkeley, 2002); Inderjeet Parmar, Foundations of the American Century: The Ford, Carnegie, and Rockefeller Foundations in the Rise of American Power (New York, 2012); and Elizabeth Borgwardt, A New Deal for the World: America's Vision for Human Rights (Cambridge, MA, 2005).

${ }^{18}$ For example, William Vogt, Road to Survival (New York, 1948); Fairfield Osborn, Our Plundered Planet (London, 1948); and E. Barton Worthington, The Ecological Century: A Personal Appraisal (Oxford, 1983).

${ }^{19}$ Anthony Cullen and Sydney Downey, Saving the Game: The Story of the Destruction and Attempts at Preservation of the Wild Life of East Africa (London, 1960), 108.
} 
from "the meat-hungry Africans who regarded all animals as their natural enemies anyway." 20 Kenya's wildlife managers were reported as believing that "if something isn't done soon ... there won't be a wild animal larger than a rabbit left alive in Africa." 21

Anxieties about conservation were further developed by contributors to the hunting genre like Robert Ruark, who combined nostalgia for a golden age of safaris and settlers with racist, dehumanizing critiques of nationalists. ${ }^{22}$ In the travel genre, writer Peter Matthiessen admitted that his first trip to Africa was motivated by a voyeuristic desire to bear witness to "the destruction of wildlife by rampaging Africans [that] had been widely predicted." 23 Fear also loomed over conservationists' meetings. At the Bukavu Conference on conservation, delegates listed "restrictions on the use of muzzle-loaders" and "restrictions relating to other firearms" as a key component of the work they had ahead. ${ }^{24}$ Conservationists cited political upheaval as the "norm." Warnings from the Congo, as that country became embroiled in Cold War politics, suggested that all of independent Africa would follow a frightening trajectory. ${ }^{25}$ The World Wildlife Fund-one of a host of new organizations dedicated to the protection of wildlife as a global trust-used its manifesto of 1961 to discuss "emergency" an "international trust," "battling" threats, funding "campaigns," "mercy missions," operations in "danger spots," and the maintenance of a "war room." 26 This militaristic language framed conservation work as conflict between humanity's highest and basest instincts, often understood in racial terms.

Military-style preparations were necessary, according to conservationists, because "in the name of advancing civilization [wild animals] are being shot or trapped out of existence on land taken to be exploited, or drowned by new dams, poisoned by toxic chemicals, killed by poachers for game, or butchered in the course of political upheaval." 27 Many conservationists regarded the modernizing aspirations of new states in Africa as incompatible with their obligations as hosts of important wildlife populations. The Fauna Preservation Society-formerly the Society for the Preservation of the Fauna of the Empire-wrote to the British Colonial Office expressing its concerns about the attitude of nationalist leaders and the "danger that when government passed into African hands, many of the existing measures for wildlife preservation and conservation would not be maintained."28 For other commentators, the problem was less about leadership, which, as I discuss below, ultimately proved instrumental to national-era conservation, than it was about the nature of Africans

\footnotetext{
${ }^{20}$ Alan Moorehead, No Room in the Ark (New York, 1959), vii, 9.

${ }^{21}$ Ibid., 110.

${ }^{22}$ Robert Ruark, Something of Value (New York, 1957).

${ }^{23}$ Peter Matthiessen, The Tree Where Man Was Born (New York, 1972), 47.

${ }^{24}$ Letters from East African Professional Hunters Association, 1934-1938, KW 5/48, KNA. See also Troisème Conférence Internationale Protection de la Faune et de la Flore en Afrique (Bukavu, 1953), 266-67, 283.

25 "The Congo," Oryx 6, no. 1 (April 1961): 27-34.

${ }^{26}$ World Wildlife Fund, "We Must Save the World's Wildlife-An International Declaration," 1961, http://wwf.panda.org/who_we_are/history/.

${ }^{27}$ Ibid.

${ }^{28}$ The National Archives (hereafter TNA), CO 847/75, letter on Colonial Game Policy in Africa, [1962].
} 
and their supposed failure to value wildlife in the same terms as Europeans. Earlier thinkers ascribed this "failure" to characteristics of a biological race, but sociological frameworks of racism increasingly came to define colonial thinking about developmental and aesthetic questions. ${ }^{29}$ As early as 1952, Kenya's national parks were promoting essay competitions among African and Asian students on the subject of "Why do we preserve wild life in this colony?"30 Some optimists observed that "here and there are indigenous Africans who are contributing to these ideas and are prepared to spread the news to their colleagues." The Africa Special Project was developed in the run-up to East African independence to "help [African] governments to help themselves to develop their wild life resources." 31 And conservation publications like Oryx , the news organ of the Fauna Preservation Society, regularly highlighted links between conservation and education. To cite merely two examples, in 1961 Oryx reported on a camp for schoolchildren at the Kafue National Park in Northern Rhodesia and a year later published a study of conservation education in Southern Rhodesia. ${ }^{32}$ The College of African Wildlife Management emerged from this context as a larger-scale effort to address the problems posed for conservation by decolonization. The college was also shaped by the context in which new states sought to defend their hard-won sovereignty.

\section{AFRICANIZATION IN TANZANIA}

When Tanzanian game warden Bruce Kinloch looked back on the 1960s, he described a narrow escape for Tanzania from the chaos that engulfed some neighboring countries. "The ominous thunder of revolution," he intoned, "revealed the writing on the wall; the days of the European game warden in Black Africa are numbered, it said. The college at Mweka had been started only just in time."33 Proximately, creating the college was a rearguard action by Kinloch, a colonial official. However, its founding was ultimately tied up in an effort to revolutionize the distribution of power in Tanzania, its wildlife sector, and its government more broadly. In some respects, Kinloch and Tanzanian president Julius Nyerere represented the poles of the political interests invested in the college. If global conditions, transnational trends, and fear of the future primed conservationists to be enthusiastic about an organization like CAWM, African states and publics witnessed the same set of developments through a different lens. As scholars of European empires and independent states alike have observed, there was no guarantee in the postwar world that colonies would follow an inevitable trajectory to majority-rule independence as sovereign

${ }^{29}$ For a good discussion of these distinctions, see Andrew Zimmerman, Alabama in Africa: Booker T. Washington, the German Empire, and the Globalization of the New South (Princeton, 2010), 205-36.

${ }^{30}$ Game Department correspondence, 1951, KW 5/46, KNA.

31 "The International Union for the Conservation of Nature and Natural Resources: African Special Project, Stage I,” Oryx 6, no. 3 (September 1961): 143-70, at 143.

32 Erica J. Critchley, "A Camp for Schoolchildren in the Kafue National Park, Northern Rhodesia," Oryx 6, no. 1 (April 1961): 35-38; John A. Pile, "Wild Life Conservation Education in Southern Rhodesia," Oryx 6, no. 5 (October 1962): 279-82.

${ }^{33}$ Kinloch, Tales from a Crowded Life, 284. 
nation states. ${ }^{34}$ However, once it became clear that decolonization would result in a continent of nation states, nationalist parties and leaders became concerned to ensure that they would actually control the levers of power within those states. Fears of encroachment by former colonial powers and anxieties about becoming the site of proxy wars between the two global superpowers meant that new states and their leadership were particularly concerned to staff state institutions with individuals whom they regarded as committed to defending their sovereignty and pushing forward the process of decolonization.

Reflecting these priorities, Africanization became an important feature of decolonization. It involved the replacement of European and expatriate staff in the public and private sector with "Africans," affirmatively defined as citizens of the new states. ${ }^{35}$ Africanization was also designed to minimize the presence of expatriates with questionable loyalties. The process began as a defensive concession by colonial powers grudgingly acceding to some nationalist demands in the 1950s. By 1953, parliamentarians were able to refer to "Africanisation" as a British "policy," tied to responsible government and development. ${ }^{36}$ The proceedings of the 1957 East African Conference noted that as Britain sought to managed the transition to selfrule of its East African territories, "there was a shortage of some 700 African clerks in the Civil Service ... There was a constant clamour for Africanization and if self-government were to come in 10 to 15 years' time, it was necessary to start now getting Africans in to the Civil Service as fast as possible." 37 The issue also loomed large in Sierra Leone's 1960 Constitutional Conference. ${ }^{38}$ It was raised in the House of Commons by Labor members concerned about lukewarm Tory commitment to a responsible transition. ${ }^{39}$

Beginning around 1960, Africanization changed from being a process managed by colonial governments to one driven by African political parties, whose members occupied key state posts even during the last few years before independence. Later still, it was overseen by African governments. Africanization was itself therefore a process subject to nationalization, but also to continued influence by former colonial authorities who were invested in influencing the post-independence decolonization of their former colonies. In some states, the term was given a national flavor ("Zambianization," for example), but it was a policy of virtually every independent

\footnotetext{
${ }^{34}$ Frederick Cooper, Citizenship between Empire and Nation: Remaking France and French Africa, 19451960 (Princeton, 2016); Luise White, Unpopular Sovereignty: Rhodesian Independence and African Decolonization (Chicago, 2015); and Gary Wilder, Freedom Time: Negritude, Decolonization, and the Future of the World (Durham, 2015).

${ }^{35}$ For some examples of the angles that scholars have taken to the subject of Africanization-seldom the direct object of study in recent scholarship-see Poppy Cullen, Kenya and Britain after Independence: Beyond Neo-Colonialism (Cambridge University Press, 2017); Mokubung O. Nkomo, "A Comparative Study of Zambia and Mozambique: Africanization, Professionalization, and Bureaucracy in the African Postcolonial State," Journal of Black Studies 16, no. 3 (March 1986): 319-42; Colin Baker, "The Administrative Service of Malawi-A Case Study in Africanisation," Journal of Modern African Studies 10, no. 4 (December 1972): 543-60. For a slightly different take on Africanization, see Esperanza Brizuela-Garcia, "The History of Africanization and the Africanization of History," History in Africa, no. 33 (2006): 85100.

${ }^{36} 515$ Parliamentary Debate, House of Commons, 15 May 1953, col. 94W.

37 TNA, CO 879/170, "Proceedings of East African Conference," 1957, 31.

38 TNA, CO 879/180, "Sierra Leone Constitutional Conference: Minutes of Meeting," 1960, 22.

${ }^{39} 658$ Parliamentary Debate, House of Commons, 19 April 1962, cols. 664-65.
} 
government, however haltingly and selectively it might actually have been pursued. The pace of Africanization was defined by the availability in the nation in question of citizens with the relevant expertise, the extent to which the continued presence of expatriates might have compromised the integrity of vital institutions, the commitment of ministers and parties to the process, and the ability or willingness of former colonial powers to impede or structure the process. Historians have described how former colonial "experts," drawn from unemployed expatriates pushed out by Africanization, came to staff new international institutions. ${ }^{40}$ But many colonial personnel-whether expert or amateur-remained at least temporarily, and sometimes for decades, embedded in the institutions of new states as well. Unintuitively, expatriates might be kept on in the armed forces, in part due to their expertise but also as a diplomatic lever. The private sector was often an even more difficult nut to crack. Andrew Sardanis, a member of the Zambian cabinet, described how the European Mineworkers Union and the companies on the Copperbelt deployed "every trick in the book to sabotage" Zambianization. ${ }^{41}$

In Tanzania, a new government assumed responsibility for Africanization at the end of 1961. The College of African Wildlife Management's creation coincided with a renewed dedication of the Tanzanian government to the Africanization of its civil service, part of a wider political campaign that involved curbing freehold title. Contrary to the boasts of nationalists and the bemoaning of expatriates, the speed of Africanization in Tanzania was due at least as much to the voluntary departure of expatriates as to the state's program to nationalize its civic infrastructure. The British government went to some pains to counter the circulation of rumors among expatriates ${ }^{42}$ stressing that few expatriates had "been 'Africanised' in the sense that they have been told to go so that an African can take their place." Rather, compensation programs, paranoia, and an unwillingness to work for African ministers drove many expatriates, particularly early on, to leave Tanzania. ${ }^{43}$

Tanzanian government press releases emphasized that "technological posts and senior posts in 'technical' ministries" would be Africanized at a much slower rate than they were in other spheres of government. ${ }^{44}$ The Tanzanian prime minister declared that Africanization would be "planned and orderly," and that there was great need for training to accompany the cultivation of African staff. ${ }^{45}$ The rate at which expatriates across the Tanzania civil service retired in the first eleven months after independence was not remarkable. The 31 percent figure put it higher than that of both the Northern and Federal zones of Nigeria at the same stage in their post-independence trajectory, roughly on par with Ghana and Eastern Nigeria, and significantly lower than that of Western Nigeria or Sierra Leone. The largest number of resignation notices in Tanzania came in the first months of 1962, but the figures quickly trailed off from the ninety to three hundred range into barely

${ }^{40}$ Hodge, Triumph of the Expert, 256-57.

${ }^{41}$ Andrew Sardanis, Zambia: The First Fifty Years (New York, 2014), 31.

42 TNA, DO 168/10, "State of the Upper Tanganyika Civil Service, 10 September 1962."

43 TNA, DO 168/10, confidential minute on Africanization, 1 August 1962.

${ }^{44}$ TNA, DO 168/10, Tanganyika Information Services, press release, 23 May 1963.

45 TNA, DO 168/10, extracts from speeches made by Tanganyikan ministers on Africanization, Tanganyika Information Services press release, 23 May 1963. 
more than a dozen per month in late 1962 and early $1963 .{ }^{46}$ Particularly in technical posts, the Tanzanian state encouraged expatriates to use the British state's Overseas Service Aid Scheme (OSAS), which topped up salaries, incentivizing expatriates to remain in place. ${ }^{47}$ Scheme funds were applied to expatriate staff across Tanzania's and East Africa's wildlife sector during the 1960s and 1970s, and only ended in Kenya when they became a casualty of Thatcherite austerity, in spite of the pleas by Kenyan authorities for the extension of the program. ${ }^{48}$ By the end of 1962, 1,523 expatriates worked under OSAS contracts in Tanzania. ${ }^{49}$ Vacancies in the Ministry of Lands, Forests and Wildlife remained comparatively low. These services were among the technical sectors singled out for slower Africanization. ${ }^{50}$ Not coincidentally, their Africanization plans were among the earliest to receive approval. ${ }^{51}$ At the upper level of administration, J. W. L. Makinda, who had served as a local government assistant secretary, district commissioner, and district officer, was appointed as the permanent secretary to the responsible ministry, but personnel working in game reserves and national parks were little affected. ${ }^{52}$

In early 1962, the Tanzanian government had created an Africanisation Commission responsible for "the detailed planning for the most rapid Africanisation of the public service that can be achieved without a severe drop in standards." 53 The commission was designed to report to an East Africa Common Services Organization commission, chaired by Jerome Oputa Udoji, the chief secretary in the Eastern Region, Nigeria, who had participated in the process of Nigerianization. British officials were privately gleeful at Udoji's appointment, believing him to possess a condescending view of East African capabilities. ${ }^{54}$ The commission and the British government also drew on the Public Officers Agreement between Britain and Ghana when formulating and evaluating Tanzania's Africanization process. ${ }^{55}$ The Tanzanian commission requested plans and timelines from each ministry, and either approved the plan or returned it to the relevant ministry for further work. British officials reported that these developments left "expatriate and business confidence ... shaken." ${ }^{~ 56}$ But the results in the wildlife sector were mixed in their

${ }^{46}$ TNA, DO 168/10, Tanganyika Information Services, press release, 23 May 1963.

47 Ibid.

48 TNA, DO 112/6, Wildlife and Tourism, Kenya, 1981. Similarly, Reagan-era austerity impacted United States National Parks Service assistance to Mweka in 1981. Toman Hutagalung and Joseph A. Sawe, "Progress Report on the Implementation of Recommendations on Regional Programmes in the Conservation and Management of African Wildlife," Joint Inspection Unit report no. 83/3 (Geneva, 1983), 16.

49 TNA, DO 168/10, "State of the Upper Tanzania Civil Service at 31st December 1962," Tanganyika Information Services, press release, 23 May 1963.

${ }^{50}$ Ibid.

${ }^{51}$ TNA, DO 168/10, confidential report on staffing in the upper civil service, 20 August 1962.

${ }^{52}$ TNA, DO 168/10, Tanganyika Fortnightly Summary, 8 December 1962. See also "Top Posts in Four Ministries Change Hands," Tanganyika Standard, 30 November 1962.

${ }^{53}$ TNA, DO 168/10, confidential report on staffing in the upper civil service, 20 August 1962.

54 TNA DO 168/10, W. G. Lamarque, deputy high commissioner, Enugu, to unknown in Commonwealth Relations Office, 6 November 1962.

${ }_{55}$ Public Officers Agreement between the Government of the United Kingdom and the Government of Ghana (London, 1957).

56 TNA, DO 201/13, "Correspondence respecting Commonwealth Relations, vol. 13, Canada, Australia, New Zealand, India, Pakistan, Ceylon, Ghana, Federation of Malaya, Federation of Nigeria, Cyprus, 
implications. As I discuss below, the general push for Africanization and the connection of Tanzania's prime minister to the wildlife sector-Rashidi Mfaume Kawawa's father was a game scout who died in government service-left its expatriate employees feeling vulnerable.

Anxiety about Africanization was, however, based more on the general atmosphere of concern than it was on actual events. The reasons for this were complex. The expertise of personnel in these technical ministries was of both practical and rhetorical importance for the Tanzanian government. But it was also the case that OSASfunded staff were not included in the government's Africanization statistics because they were regarded as contract rather than expatriate labor, whether or not the individual in a given post had carried over from the colonial period. Therefore, even if it was colonial nostalgia and fear that led to the use of OSAS funds to ensure the continued presence of expatriates in the wildlife sector, those personnel did not disrupt the Tanzanian government's Africanization statistics or the "horse race" between ministries to meet targets; press releases routinely announced progress and celebrated high-profile examples of Africanization. ${ }^{57}$ In other ministries, the percentage of staffing by OSAS personnel ranged from a low of 16 percent (in the Prime Minister's Office) to a high of 52 percent (in the judiciary). A plurality of departments-including Local Government, Communications, Education, Health and Labour, Home Affairs, Exchequer, and Treasury-were around the 30 percent range. Lands, Forests and Wildlife were the highest at 57 percent. ${ }^{58}$ Indeed, no officers in that ministry were given notice, at least within the first nine months of independence, and the British government actually cited a need for additional European game wardens for the coming years, believing that they could be recruited in the region, indicating either that Africanization might have moved more swiftly elsewhere or that the conservation "boom" had increased the number of would-be conservationists operating in East Africa. ${ }^{59}$ The British government, a key participant in post-independence Africanization, therefore envisioned not increased Africanization but increased "expatriatization" of the wildlife sector in order to maintain the number of personnel capable of managing the state's expanded ambitions. Tanzania's own Africanization report did not envision the Africanization of game wardens during at least the first five years of independence. ${ }^{60}$ The report identified twenty-three expatriates in the upper reaches of the Game Department and described the department as "a disciplined armed force with considerable powers of law enforcement and responsibility for the collection of substantial revenue."61

These numbers, observations by the British government, and commission frameworks created by the Tanzanian state tell a very different story from the fears exchanged between individual British officials and their expatriate interlocutors, who described the shrinking number of the "decent element" in the Tanzanian government, the "rot" generated by Africanization, the "reckless pace" of the process,

\footnotetext{
Sierra Leone, Tanganyika, Jamaica, Trinidad and Tobago, Uganda, Federation of Rhodesia and Nyasaland, miscellaneous," 1962: 431.

57 Ibid.

58 Ibid.

59 Ibid.

${ }^{60}$ Report of the Africanisation Commission, 1962 (Dar es Salaam, 1963).

61 Ibid., 6.
} 
and the "intolerable" conditions faced by expatriates. ${ }^{62}$ The $\mathrm{BBC}$ went so far as to forecast that there was a danger that "the administration of the country and some of its important services may come to a halt." ${ }^{\prime 63}$ More sober assessments by British officials stressed that much of the disorder that critics witnessed in Tanzania's administration had little to do with the departure of expatriates and more to do with the expanding mandates and ambitions of national states. ${ }^{64}$ By mid-1963, the regular dispatch from the British High Commission in Dar es Salaam had to concede that the effect of Africanization on the civil service had "not been too serious" and that expatriate officers still had a key role to play in administration. ${ }^{65}$

\section{FOUNDING THE COLLEGE}

Global conservationists' concerns and an Africanization project shaped by state ambitions and British funding provide some of the context for the emergence of the college. Also important was the local history of conservation, the circulation of personnel and ideas in the late colonial era, and the outlook of Tanzania's executive. In spite of the limited impact of Africanization on Tanzania's wildlife sector, individual expatriate members of that sector were nonetheless convinced by the apocalyptic rhetoric in conservation circles and the government's own rhetoric. Thus, their activism, as well as the broad structural imperatives of decolonization, shaped the college's foundation. Bruce Kinloch, who claimed the college as his brainchild, was a deputy to Ugandan game warden Charles Pitman and later warden in his own right. The Ugandan Game Department, while committed to preserving the colony's wildlife, also had a tradition of substantial culling of elephants, hippos, and buffalo in the service of development, and a strongly ecological bent that by the late 1950s distinguished it from other wildlife departments in East Africa. ${ }^{66}$ Kinloch, like Pitman (referred to in the British press as "the elephant's enemy"), was a proponent of wildlife conservation rather than preservation. ${ }^{67}$ No misty-eyed sentimentalists, the Ugandan department's wardens were known as proponents of aggressive and sometimes bloodthirsty management, something that reflected the management sensibilities of particular European employees, the comparative absence of settlers, the relative power of indigenous authorities, and the concomitant emphasis on African-oriented development. In 1960, Kinloch became the head of Tanzania's Game Department, bringing with him the philosophy of management and control. Tanzania's colonial game reports bear witness to a wildlife sector that

${ }^{62}$ TNA, DO 168/10, British High Commission, Dar es Salaam, to Commonwealth Relations Office, 5 April 1962.

${ }^{63}$ TNA, DO 168/10, text of a broadcast to BBC and KBS by Mr. Douglas Willis, BBC correspondent, 16 March 1962.

${ }^{64}$ TNA, DO 168/10, draft memorandum, Commonwealth Relations Office, on Africanization in Tanganyika, undated [February 1962].

${ }_{65}$ TNA, DO 168/11, acting high commissioner, Dar es Salaam, to secretary of state for Commonwealth Relations, 26 June 1963.

${ }^{66}$ See, for example, Charles Pitman, A Game Warden Takes Stock (London, 1942) and Charles Pitman, A Report on a Faunal Survey of Northern Rhodesia (Livingstone, 1934).

67 "Uganda Game," London Times, 31 July 1929. 
needed little convincing on the merits of animal control. ${ }^{68}$ But the Ugandan influence introduced a stronger emphasis on the need to embed control and conservation work in the context of development. In 1961 Kinloch presented a paper, "The Urgent Need for Formalized Training Facilities for Wildlife Management Personnel in the Africa of Today," to an East African conservation conference. He began by evoking British prime minister Harold Macmillan's "winds of change" speech, and then identified a second gust on the horizon: "a wind of urgent enquiry and investigation" to blow away the "mists of misconception to reveal the vital role that the great game animals can play in the development of this continent and the advancement of its peoples."69 Based on an earlier internal document, Kinloch's paper argued that the more complex environment facing African parks and protected areas after independence required formalized training that treated wildlife management as "a true branch of natural science comparable with forestry and agriculture."70

Kinloch reported that his paper was well received. It was at this point that an intervention from Tanzania's prime minister provided both anxiety and opportunity for Kinloch's project. Julius Nyerere resigned the premiership in 1962 to crisscross the country in advance of a presidential campaign designed to secure a sweeping mandate for social and economic change in Tanzania. His temporary replacement was Rashidi Mfaume Kawawa, who had a reputation as a "strong protagonist of Africanisation."71 While perusing a paper, Kawawa happened upon a Game Department advertisement for a contracted "European Game Warden" and wrote asking the department to do its part in "accelerating Africanization" by finding a way of bringing Tanzanians into the pipeline for promotion. Kinloch's supervising minister, Tewa Saidi Tewa, passed along the note with an injunction to act on its contents. Kinloch believed that the advertisement caught Kawawa's eye because the prime minister's father had served as a game scout and died while serving the department. ${ }^{72}$

At first, Kinloch saw in the ministerial missive base political patronage rather than an opportunity. He portrayed Africanization as a threat, invoking "the horrors of the Congo [as] a sobering example of what can happen when discipline goes, training is forgotten, and armed men go on an extended rampage." In protesting to the minister, he noted that "there were over six hundred, tough, well-armed game scouts in the Tanganyika Game Department; a force which could terrorise the countryside if they got out of control." 73 The language of internal security was one that newly independent governments spoke as fluently as their colonial-era predecessors, given anxieties about national breakup and well-founded fears of neocolonial intervention in a Cold

\footnotetext{
${ }^{68}$ See Tanganyika Territory, Game Preservation Department Annual Reports, 1930s-1950s (Dar es Salaam, n.d.).

${ }^{69}$ Kinloch, appendix 1, Tales from a Crowded Life, 305.

${ }^{70}$ Ibid., 306.

${ }^{71}$ TNA, DO 201/13, "Correspondence respecting Commonwealth Relations, vol. 13, Canada, Australia, New Zealand, India, Pakistan, Ceylon, Ghana, Federation of Malaya, Federation of Nigeria, Cyprus, Sierra Leone, Tanganyika, Jamaica, Trinidad and Tobago, Uganda, Federation of Rhodesia and Nyasaland, miscellaneous,” 1962: 435.

${ }^{72}$ Kinloch, Tales from a Crowded Life, 270-71.

${ }^{73}$ Kinloch, The Shamba Raiders (Southampton, 1988), 331.
} 
War context. ${ }^{74}$ Indeed, during a military mutiny in early 1964, the armory at the then-established college was kept under careful guard. ${ }^{75}$ But despite these early misgivings, Kinloch slowly came to embrace as his mission the creation of a training college to keep expatriates employed and influential in the short term.

Kinloch envisioned the proposed college as an institution complete with specially designed coursework-blending the academic and the practical-to educate and train the first generation of African wardens. To that point, Africans had served in Uganda as rangers, undertaking control duties themselves with little active supervision by European wardens. The situation was similar in Tanzania and Northern Rhodesia. In Kenya, the leash on African participation was tighter, particularly in relation to firearms. ${ }^{76}$ Lord Hailey cited "primitive weapons" and "tribal warfare" as the only thing that had stood between pre-colonial African societies and the slaughter of wildlife. ${ }^{77}$ Concern about the effect of armed Africans on wildlife populations even drove the Northern Rhodesian state close to total confiscation of firearms in the 1950s, before cooler heads prevailed. ${ }^{78}$ All of that would have to change in the coming years. With an eye on region-wide changes, Kinloch developed a training program, identified a site at an old school at Mweka, and set about gathering the necessary funding, most of which had to come from outside of the Game Department's budget.

\section{THE NATIONAL CONTEXT}

Of course, the college required more than a minister's prodding, Kinloch's initiative, and funding. It required the support from the government of its now-independent host and a stamp of approval-legal and moral-from Tanzania's leadership. Soon after independence, local and international preservationists paid a call on the leader of Tanzania's ruling party, Julius Nyerere. Known as Baba wa Taifa ("father of the nation") and Mwalimu ("teacher"), Nyerere became a revered figure in Tanzania and was at the forefront of both the nationalist movement that brought the country independence and post-independence efforts to stimulate new development, new forms and bases of solidarity, and new habits of mind. ${ }^{79}$

Nyerere's response to the preservationists reflected the economic reality of the post-independence era rather than any personal conservationist evangelism. "Personally," he supposedly told his guests, "I don't care much about wild animals ... I can't imagine myself spending my leave looking at crocodiles. But I know Europeans and Americans like doing so, I know they want to see elephants and giraffes. Tanganyika still has most of the wild animals in all Africa. I will ensure that tourists can see them.

\footnotetext{
${ }^{74}$ For good overviews of these perils, see Elizabeth Schmidt, Foreign Intervention in Africa: From the Cold War to the War on Terror (Cambridge, 2013), and Paul Nugent, Africa since Independence (New York, 2012).

75 "Notes and News," Oryx 7, no. 4 (April 1964): 143-52, at 145.

76 "Administration of the Game Laws, 1956," KW 15/16, KNA.

77 Lord Hailey, An African Survey, Revised 1956 (London, 1957), 926.

78 "Record of a meeting held on 8 January 1954 to consider the question of a reduction of firearms held by the public in Northern Rhodesia," SEC 6/371, NAZ.

${ }_{79}$ Priya Lal, African Socialism in Postcolonial Tanzania: Between the Village and the World (Cambridge, 2015); Julius K. Nyerere, Uhuru na Ujamaa, Freedom and Socialism (London, 1968).
} 
In my judgment, after sisal and diamonds, Tanganyika's wild animals will become the third most important source of income our country has." 80 A 1963 story in Kenya's Daily Nation linked conservation to development in a similar fashion, light-heartedly citing the opening of CAWM as "an important step in the task of game preservation, the means to the end of gently separating the tourist from his money." ${ }^{\prime 1}$ In 1965, preservationists would identify Nyerere's intervention as crucial for resettlement programs that evicted villagers from protected areas in and around the Serengeti National Park. ${ }^{82}$

After negotiations about how to express his support for conservation in Tanzania, Nyerere had in 1961 signed the Arusha Manifesto, a document written by World Wildlife Fund personnel that became an oft-cited statement of good faith on the part of African leaders toward conservation:

In accepting the trusteeship of our wildlife we solemnly declare that we will do everything in our power to make sure that our children's grand-children will be able to enjoy this rich and precious inheritance. The conservation of wildlife and wild places calls for specialist knowledge, trained manpower, and money, and we look to other nations to co-operate with us in this important task the success or failure of which not only affects the continent of Africa but the rest of the world as well. ${ }^{83}$

Nyerere, among the new generation's most trenchant critics of the colonial order, had embraced the language of universalism out of economic expediency. However, the conservationist-authored manifesto outlined the commitment of African nations in the form of a bargain. Although it adopted the language of trusteeship long deployed by imperial preservationists who had argued that Africa's wildlife was of value to the whole world, the manifesto also outlined expectations of how European and American governments and organizations should be prepared to assist. The establishment of the college can be read as an example of neocolonial institutions flexing their power in vulnerable new states to pursue their own ends and subvert Tanzania's sovereignty. However, when embedded in the politics of decolonization and Africanization, it is clearly also an example of an independent government leveraging global interest in its affairs to its own economic ends. Indeed, Tanzania's Africanization Commission reported favorably on the creation of the college from precisely this perspective in $1962 .{ }^{84}$

Nyerere was not alone among post-independence leaders in seeing wildlife conservation as important for economic development and aesthetics and in its implications for sovereignty. Kenya's Jomo Kenyatta portrayed himself as a patron of his country's wildlife and even offered Ahmed, an exceptionally large-tusked elephant, a presidential guard. ${ }^{85}$ Striking a slightly different tone and openly locating historical hostility to wildlife in the context of the nationalist struggle, Zambia's prime minister

${ }^{80}$ Bernhard Grzimek, Rhinos Belong to Everyone, trans. Oliver Coburn (New York, 1965), 173-75.

81 "No Time for This Holier-Than-Thou Attitude," Daily Nation, 28 July 1963. The story added, "The elephant is an ugly, dangerous, destructive beast, useless for any form of work, unbeautiful to the eye. Yet it is worth his weight in dollars, and for that reason only well worth preserving."

82 "Notes and News," Oryx 8, no. 2 (August 1965): 75-82, at 81.

${ }^{83}$ Raymond Bonner, At the Hand of Man: Peril and Hope for Africa's Wildlife (New York, 1993), 64-65.

${ }^{84}$ Report of the Africanisation Commission, 1962, 6.

${ }^{85}$ John Clemans, "The Life and Death of Ahmed," Sunday Post (Dundee), 20 January 1974. 
Kenneth Kaunda tied post-independence conservation to the viability of his new state. In a September 1964 memo circulated to government officials just one month before independence, Kaunda wrote:

In the past, many people killed game unlawfully and interfered with the work of the Game Department. They did this as a way of helping in the struggle for independence. Now we have our own government and it is we who employ the game guards and game scouts and game rangers. Now it is the duty of everyone to assist our Game Department in catching poachers and bringing them before the courts for punishment, and I want it clearly understood that the officers and men of my Game Department have my full support in their difficult and important task of looking after the national herds. ${ }^{86}$

Statements like these demonstrated the extent to which preservationists had underestimated nationalists and independent governments. Nyerere, Kenyatta, Kaunda, and others were prepared to act on the potential of tourism in a much more systematic fashion than had the colonial state. Their unequivocal claims to state sovereignty in parks were directed as much at their own citizens as at expatriate interlopers. But preservationists' international efforts also created a much more favorable financial climate for conservation work in Africa.

Although efforts surrounding the college site at Mweka and the recruitment of students began earlier, its status was confirmed by the passage of an act of parliament. The National Assembly formally passed the measure on 18 February 1964, and on 5 March, Nyerere added his signature. "An Act to Establish the College of African Wildlife Management" stipulated that the college had the goal of "providing in Tanganyika facilities for the training of students in the management of the wildlife of Africa." 87 The act established CAWM as a corporate entity, created a governing body, and outlined the position and duties of the principal, who was appointed by the board with ministerial approval. The principal oversaw the day-to-day academic and administrative affairs of the college. ${ }^{88}$ The legislation left the college with great lateral movement to seek financial support outside of Tanzania, although it had to present an annual budget to the board. In addition to formalizing the college's status, the Tanzanian government applied for assistance from the United Nations Development Programme (UNDP) Special Fund. The successful application yielded more than US\$.5 million in support, which came in the form of fellowships, equipment, and 230 man-months of "expert services." A second application in 1969 generated a project evaluation. Members of the evaluating mission concluded that in broad terms the college "made a valuable contribution to the conservation and development of African wildlife through the training of medium-grade personnel." 89

Conceived as an answer to the problem of Africanization, CAWM's arrival on the conservation scene resonated across the region. It was received enthusiastically not only by international funders but also by Kenyan wildlife authorities who on the

${ }^{86}$ Memo from Kenneth Kaunda, 17 September 1964, EP/1/1/21 Loc 465, NAZ.

${ }^{87}$ Tanganyika Parliament, "An Act to Establish the College of African Wildlife Management," (Dar es Salaam, 1964).

${ }^{88}$ Ibid., 1-2.

89 "Notes and News," Oryx 8, no. 3 (December 1965): 147-55, at 152; "Report of the Joint UNDP/ FAO Evaluation to Tanzania," January 1979, KW 4/8, KNA. 
eve of independence were under pressure to Africanize their department but lacked institutions or mechanisms for training and promoting Kenyans within the wildlife sector. ${ }^{90}$ One sign of the college's significance was the global funding it attracted.

\section{GLOBAL CONNECTIONS AND FUNDERS}

The new conservation climate and its world-wide web of environmentalists led the Tanzanian state and Kinloch to look for global funding. International supporters of the college were varied. Bernhard Grzimek's Frankfurt Zoological Society had already established roots in Tanzania through its work in the Serengeti and became a leading supporter of CAWM. ${ }^{91}$ Russell Train's African Wildlife Leadership Foundation made its inaugural foray into the conservation world through its support of the college. The UNDP and the US Agency for International Development also played significant roles. Train was an American judge who later became the director of the US Environmental Protection Agency and the head of the World Wildlife Fund's US branch. He was inspired by two safaris to East Africa, and upon his return to Washington, DC, resolved to contribute something to the region's wildlife scene. Citing as a pressing issue unsustainable human population growth, Train articulated his desire to develop an organization devoted to "the most important wildlife conservation task in Africa, [to] help Africans equip themselves with the knowledge and skills ... to manage their own wildlife resources."92

The African Wildlife Leadership Foundation (AWLF), run out of Train's own office in its early years, provided funds for the education of those who were identified as promising Africans, and was instrumental in funding CAWM. Early on, Train cultivated Perez Olindo, future director of the Kenya National Parks Authority. Known for his sense of style, Olindo once tackled a panga-armed fleeing poacher in "the best rugby tradition" while wearing a pin-striped suit ${ }^{93}$ and spent a fifty-year career in the wildlife sector of East Africa. Train was a consummate networker, and his work brought together Washington socialites, Paul Mellon's Old Dominion Foundation (now the Andrew W. Mellon Foundation), the Rockefellers, the African American Institute, Interior Secretary Stewart Udall, and A. Starker Leopold, a University of California, Berkeley professor and son of renowned wildlife scientist Aldo Leopold. ${ }^{94}$ Kinloch recalled how he wrote to Grzimek and Train asking for $£ 10,000$. "In both cases," he remembered, "the response was immediate. Bernhard Grzimek wrote from Germany to say that the Frankfurt Zoological Society had made an initial donation to the value of $£ 2,000$ and more would follow. Russell Train cabled from Washington saying that the AWLF was sending $\$ 25,000$ and to

\footnotetext{
${ }^{90}$ Chief game warden to permanent secretary at the Ministry of Tourism, Forests, and Wildlife (Kenya) and the director of the Royal National Parks, 4 March 1963, KW 4/4, KNA.

${ }^{91}$ See Bernhard Gissibl, The Nature of German Imperialism: Conservation and the Politics of Wildlife in Colonial East Africa (New York, 2016), 304-7. 41 .

${ }_{92}$ Russell E. Train, Politics, Pollution, and Pandas: An Environmental Memoir (Washington, DC, 2003),

${ }_{93}$ Stan Bleazard, "Call Me Al," in Ian Parker and Stan Bleazard, eds., An Impossible Dream: Some of Kenya's Last Colonial Wardens Recall the Game Department in the British Empire's Closing Years (Moray, Scotland, 2001), 291-98, at 291-92.

94 Train, Politics, Pollution, and Pandas, 40-49.
} 
whom should it be paid?"95 Paternalistic in character but practical in orientation, the AWLF in particular proved an ideal fit for the college, given the circumstances and timing of its birth.

The benefits of the relationship between the college and its funders were mutual. The college got off the ground and received more support than the Tanzanian state could have readily provided on its own. The Tanzanian state proved that it could leverage international funding and gained goodwill for a proactive approach to conservation. A significant proportion of college operations were funded from external resources. Funders not only accomplished policy goals; for new entrants onto the conservation scene like the AWLF, success at Mweka established their credentials as effective, serious, and trusted conservation advocates. Informational material from the later 1960s celebrated AWLF's involvement with CAWM, and indeed, the African Wildlife Foundation's website cites the college as its first project. ${ }^{96}$ Meanwhile, Kinloch engaged in shuttle diplomacy to secure both funding and personnel, tapping into the colonial civil service network as well as his connections in the conservation world. Once when traveling between Nairobi and London, he secured his own berth by posing as a "monkey attendant" for an animal export company. ${ }^{97}$

As the college came into being, its structure, curriculum, personnel, and continued funding became other sites of discussion and debate. Funding varied considerably over the first two decades of its existence. Between 1963 and 1976, the Tanzanian government provided the lion's share (US\$2,549,032) of the $\$ 3,686,433$ spent on the college. The UNDP and the Food and Agriculture Organization of the United Nations (FAO) and the German and American governments were by some distance the next-largest contributors, with funding from those sources running into the hundreds of thousands of dollars. The AWLF gave over $\$ 50,000$, and the Frankfurt Zoological Society and assorted other conservation groups between them provided just under \$30,000. Between 1976 and 1982, the balance shifted, with the contributions of the Tanzanian government falling to only about one-fifth of the total contributions. The Danish government provided nearly $\$ 1.5$ million, support from the German government remained considerable, and the Kenyan government provided around $\$ 15,000$. The UNDP and FAO increased their contribution, while the United Nations Environment Programme and UNESCO joined the ranks of major funders. Student fees also rose, meaning that some foreign governments sponsoring CAWM students also saw their contributions increase. ${ }^{98}$ Elizabeth Garland has suggested that nationalization in 1975 adversely affected global funding for the college, but in reality from 1976 both the raw amount and proportion of funds for the college provided by external funders rose dramatically. ${ }^{99}$

${ }^{95}$ Kinloch, Tales from a Crowded Life, 276.

${ }^{96}$ AWLF pamphlet, 1969, CAWM, KW 4/1, KNA; African Wildlife Foundation, "Our History," http://www.awf.org/about/history.

${ }_{97}$ Kinloch, Tales from a Crowded Life, 279.

${ }^{98}$ Hutagalung and Sawe, "Progress Report," 16.

${ }^{99}$ Garland, "State of Nature," 160. 


\section{THE COLLEGE TAKES SHAPE}

CAWM's organizational structure reflected the complicated world from which it emerged. The college governing board needed members, and some external interests wanted the balance of representation tipped toward outside funders and private members. In its first year, Tanzania, Kenya, and Uganda were each represented by two members. The vice-chancellor of the University of East Africa, the secretary general of the Commission for Technical Co-operation in Africa, and the East African Common Services Organization each had one representative. These interests, between them, nominated three additional private members, and the East African Common Services Organization member was the chair. ${ }^{100}$ The eventual makeup tilted the balance more towards representation from African states: four government representatives from Tanzania; two each from Kenya and Uganda; one each from Zambia and Nigeria; and one representative each from the East African Community, the Organization of African Unity, the FAO and the UNDP, the AWLF, the Union of Conservation Scientists, and the World Wildlife Fund. ${ }^{101}$

In 1975, Tanzania assumed control over appointments to the board. Disagreement over the college, its autonomy, and its governance was understandable, since it represented resources, control over which gave different parties the opportunity to shape conservation in their image. Kinloch freely admitted to riding "rough-shod through further civil service principles" early on by using the East African Wildlife Society and a private bank account to circumvent early state control over the funds he received from donors. ${ }^{102}$ But by increasing its representation on the board, Tanzania as an independent state pushed back at the informality of conservation advocates.

As the representatives from Zambia and Nigeria on its board suggest, the college was designed to serve African wildlife departments well beyond the borders of Tanzania and even East Africa. When the college's first cadets paraded at its opening ceremony, they represented Tanzania, Kenya, and Uganda, but they were soon joined by students from Nyasaland, Cameroon, and beyond. ${ }^{103}$ Diploma and certificate seekers could not apply to the college as private individuals but had to be nominated and sponsored by a wildlife department in their host country, vesting further control in national departments to provide the contours for the flow of expertise and opportunity. ${ }^{104}$ Students were described as varying "considerably in age, experience and education," but many possessed at least a Cambridge School Certificate. Poor command of English posed an insurmountable difficulty for a few. The college's principal noted with interest that "the best progress had not always been made by those with the best educational background. Some hard work has been put in by some of those with relatively little education and there seems to be a tendency for the education gap to be progressively reduced." 105 Here he was referring to the ex-soldiers

100 Tanganyika Parliament, "An Act to Establish the College of African Wildlife Management," 5.

${ }^{101}$ S. K. Eltringham, Recommendations for a Comprehensive Wildlife Research Program, Tanzania (Gland, Switzerland: UNESCO, 1980), 48.

${ }^{102}$ Kinloch, Tales from a Crowded Life, 277.

${ }^{103}$ Ibid., 283.

${ }^{104}$ AWLF to John Mutinda, chief game warden, Kenya, undated 1974, KW 4/9, KNA. The rule did not stop individuals who were inspired by their experiences with the Wildlife Clubs of Kenya from seeking individual spots at the college.

105 "Notes and News," Oryx 7, no. 4 (April 1964), 146. 
who, in the tradition of the men they were being trained to replace, made up a significant proportion of students.

The New York Times in 1970 described CAWM's curriculum as "a mixture of the exotically practical and the demandingly theoretical." 106 Instruction at the college drew on the ethos of the colonial game wardens who ran the college, supplementing classroom learning with significant time in the field. Classroom subjects included law, administration, vertebrate zoology, firearms training and ballistics, vehicle mechanics, astronomy, biology, road construction, range management, and more. Field subjects ranged equally widely and included hunting and control of dangerous animals, capture and handling of animals, taxidermy, safari organization, mountain work, vegetation analysis, algae and angiosperms, field dressing and trophy presentation, and many additional topics. ${ }^{107}$ Fieldwork itself occurred in protected areas across East Africa (including Kenya's Tsavo National Park) and was deadly serious. Not only did it involve confrontations with formidable animals in dense bush but students participated in large-scale culling exercises designed to destroy animals threatening crops or human habitation. In 1970, a college outing involved killing 114 elephants in one month. ${ }^{108}$ Culling at Tsavo was one of the most significant wildlife controversies of the post-independence years, meaning that CAWM's students were exposed to the politics as well as ecology of park administration. ${ }^{109}$

The vast (and probably slightly unwieldy) curriculum was designed to transform the future wardens of Africa into the jacks-of-all trades that their European counterparts had aspired to be, albeit with more rigorous scientific training than most of those earlier wardens had possessed. The curriculum may have been somewhat illusory. Hugh Lamprey, CAWM's early principal, suggested that the college placed most emphasis on "protection and control," the historic mainstays of game, control, and parks departments for the past half century. ${ }^{110}$ The wide-ranging curriculum existed on paper at least, in spite of efforts by the Tanzanian parliament to tilt the balance from administration toward science. While recognizing the value of the law enforcement and physical components of wildlife management work, parliamentarians believed that what separated the exceptional from the average wildlife expert was their status as "competent field naturalists ... [who recognized] that answers to important questions could be obtained only by research." 111

It was not only in the curriculum focus on administration and law enforcement, however, that the college sought to emulate colonial institutions. CAWM's leadership endeavored to develop its own ethos and "games" culture by sponsoring a range of social programs and outings. Sports included soccer, basketball, and volleyball and involved competition with neighboring institutions like the Marangu Teachers' Training College, and with college instructors. One CAWM newsletter observed

106 Charles Mohr, "Safaris Are Field Work at a College for Game Wardens," New York Times, 16 December 1970 .

${ }^{107}$ Mweka Training College for African Wildlife Management, 1969-1972, KW 4/8, KNA.

${ }^{108}$ Mohr, "Safaris Are Field Work."

109 See Jeff Schauer, "The Elephant Problem: Science, Bureaucracy, and Kenya's National Parks, 1955 to 1975," African Studies Review 58, no. 1 (April 2015): 177-98.

${ }^{110}$ H. F. Lamprey, "College of African Wildlife Management: A Syllabus," African Journal of Ecology 2, no. 1 (August 1964): 75-77, at 76.

111 Notes on National Assembly meeting, 18 February 1964, KW 4/2, KNA. 
that "the instructors' soccer team under the captaincy of Les Robinette [a USAID employee] lost 2-1 to a student team led by Nagoub," optimistically predicting "that this result will be reversed at the next meeting." 112 Students participated in organized debate and defended and contested the motion, of which Nyerere might have approved, "that a one party system was better than a multi-party system."113 The AWLF and the US Department of the interior sponsored student visits to the United States. An unnamed student met with US National Parks and Bureau of Sports and Fisheries and Wildlife personnel on a 1965 visit, participated in tracking a grizzly bear, visited the Grand Canyon training site, and "attended a conference at UC Berkeley on the support of wildlife management teaching at a university in East Africa." 114 The student also delivered lectures and sought to stimulate support for conservation schemes. ${ }^{115}$

Joseph Mburugu, another college visitor to the United States, suggested on his return that parks in Africa should adopt the visitor-friendly approach of North American parks by opening visitor centers and museums, hosting nighttime programs, and developing master plans. He also described a "game commission ... for dealing with damage claims by wildlife" organized in Colorado that he believed should be emulated in East Africa. He used his experience of the game commission to critically evaluate Kenyan wildlife policy, suggesting that it was contradictory for the Kenyan government to claim to support the human interest in wildlife while refusing to take responsibility for damage caused by those animals. ${ }^{116}$ One wonders whether Mburugu's views were shaped by having experienced the sharp end of wildlife policy in some fashion before coming to CAWM.

Exchanges worked both ways. Department of the Interior personnel and German Volunteer Services instructors taught at Mweka, illustrating the globalization of wildlife expertise and exchange. Some expatriate or visiting instructors hoped that Mweka graduates would not only serve successfully in the wildlife sphere but would become conduits of information about the value of wildlife to broader national populations in Africa. ${ }^{117}$ The flow of information and expertise, however, was generally assumed to be unidirectional. Exchanges aside, European and American actors were supposed to be the purveyors of wisdom and experience in this relationship that remained structured by hierarchies of development and knowledge that mapped along racial lines.

Nonetheless, CAWM drew students from across Africa. By 1974, the diploma and certificate courses enrolled students from Tanzania, Kenya, Ghana, Nigeria, Botswana, Malawi, Uganda, Zambia, Ethiopia, and Somalia. Those students represented a range of different kinds of conservation organizations, which in turn represented the increasing variety of conservation activities pursued in East Africa and beyond. Students came from game and national parks departments in Tanzania, Kenya, Ghana, Uganda, Botswana, Zambia, Malawi, and Ethiopia. The

\footnotetext{
112 "Courses of Instruction in Wildlife Management, Mweka Training School," Mweka newsletter, 1967, KW 4/4, KNA.

113 CAWM newsletter, April 1969, KW 4/4, KNA.

${ }^{114}$ CAWM newsletter December 1964 and January 1965, KW 4/5, KNA.

115 Ibid.

116 Joseph Mburugu, memo on his trip to the United States, 28 January1964, KW 4/4, KNA.

117 Mohr, "Safaris Are Field Work."
} 
Ngorongoro Unit from Tanzania, the Natural Resources Department from Nigeria, and the Livestock and Game unit from Somalia were also represented. ${ }^{118}$

The growing number of students kept the college on a secure financial footing. Ten years after its founding, the college recorded an annual surplus of around 34,000 Tanzania shillings. Its largest expenditures were on "domestic/general" expenses, staff pay, the workshop, and laboratories. The annual subsidy from the Tanzanian government amounted to about 10 percent of its total revenues, the bulk of its total funds coming from the fees paid by its roughly eighty students and the mess charges paid by the boarders. ${ }^{119}$ However, the college's capacity was insufficient to absorb Kenya's trainees, leading the Kenyan government to seek funding for its own training institute as part of a \$17 million Tourism and Wildlife Project, substantially underwritten by a World Bank loan. ${ }^{120}$

In the estimation of its founders and promoters, CAWM was a success. The Fauna Preservation Society had been enthusiastic in heralding the college's arrival on the scene, noting that it addressed an "urgent" conservation need. ${ }^{121}$ The society included Mweka on its itinerary for its 1966 tour of East Africa. ${ }^{122}$ Rennie Bere, sometime director of the Uganda National Parks, wrote in the 1970s that "in 1964 Francis Katete, the first Ugandan director and first of us to be properly qualified for his job [thanks to his training at CAWM] took over [the parks service]."123 S. K. Eltringham, who founded the Nuffield Unit for Tropical Animal Ecology in Entebbe, Uganda, deemed the training offered at Mweka superior to that available at the University of Dar es Salaam. ${ }^{124}$ The Tanzania National Parks celebrated the college as a "watershed" and "a source of national pride." 25 The college budget took pride in receiving funding from diverse sources including the US Agency for International Development, the Federal Republic of Germany, the AWLF, the FAO, the Zoological Society of Frankfurt, the British government, and other organizations. ${ }^{126}$

Yet for some donors and conservation activists, Tanzania's national politics became a source of concern about the college in particular and Tanzania's environmental commitments more generally. The Tanzanian government sought to address these worries. Derek Bryceson, a member of parliament and former government minister for Nyerere's Tanganyika African National Union party, became director of the Tanzania National Parks during the 1970s. Bryceson's presence in parliament was cited by British MPs as evidence of Tanzania's goodwill toward expatriates, and his appointment was probably strategic. ${ }^{127}$ His marriage to primatologist Jane

118 CAWM newsletter, January to June 1974, KW 4/9, KNA.

119 CAWM estimates for 1974-75, KW 4/9, KNA.

${ }^{120}$ Report no. 1022-KE, Republic of Kenya, Appraisal of the Wildlife and Tourism Project (Tourism Projects Department, 1976), Annex 4, 1, http://documents.worldbank.org/curated/en/4623 71468273052007/pdf/multi-page.pdf.

121 "Notes and News," Oryx 7, no. 4 (April 1964), 145.

122 "The FPS East African Tour," Oryx 8, no. 4 (April 1966): 219-20, at 220.

123 "The Story of the Uganda National Parks," RCMS 170: 8/9, Royal Commonwealth Society Library, Cambridge University Library.

${ }^{124}$ Eltringham, "Recommendations," v, 48.

125 Tanganyika National Parks, Report of the Board of Trustees (Arusha, 1964), 18.

126 CAWM accounts, 1969, KW 4/8, KNA.

127720 Parliamentary Debate, House of Commons, 12 November 1965. 
Goodall, who ran the Gombe Stream Research Centre in Tanzania, solidified his conservationist credentials. Bryceson and Goodall coauthored a five-page article in a 1975 special edition of Africana magazine devoted to a discussion of conservation in East Africa. The issue also included a page-long interview transcript between Bryceson and conservationist Esmond Bradley Martin. ${ }^{128}$ Bryceson's status gave the article and interview official status, and Goodall's presence in the byline ensured that conservationists understood the intertwining of state and conservationist policy.

The article emphasized the college's significance for Tanzania's long-term development of its conservation and tourist infrastructure and the personal interest of Nyerere ("a keen botanist with considerable knowledge of the vegetation") and offered specific examples of how the college had elevated Tanzanians to positions of leadership in the wildlife sector. ${ }^{129}$ In the interview, Bryceson also offered direct reassurances to anxieties about the nationalization of the college in 1975. He argued that the major overhaul was curricular, with little effect on institutional integrity. He was, however, uncompromising in his defense of the idea that "instead of other African countries and conservation organizations appointing the governing body of the College," the Tanzanian government should appoint board members. ${ }^{130}$ As a whole, the Africana issue took an upbeat view of conservation in Tanzania in comparison to its evaluation of Kenya, where it suggested that parks would be eroded in the name of "lebensraum." satisfaction was based on factors that were interpreted differently by other college constituents.

\section{COLONIAL CONTINUITIES}

The college's celebrated technocratic and financial successes did not entirely mask some of the cultural and political continuities it represented, and these issues troubled students and onlookers. Although CAWM was supposed to facilitate the Africanization of game and national parks departments across the region, there were times when it seemed to reconstruct the very colonial relationships it was meant to replace. Many members of its staff were wardens or directors who, feeling the pinch of Africanization in their home departments, struck out for Mweka to maintain a role in the wildlife sphere in Africa. Even a few old-time big game hunters were hired to teach at the college. ${ }^{132}$ One such hunter, Ernest Hemingway's son Patrick, was hired by the FAO, a status enjoyed by other expatriate employees; ${ }^{133}$ in 1964, the college principal, H. F. Lamprey, a British citizen, was technically employed by the FAO. ${ }^{134}$ Hemingway's pay was split between the FAO and the

\footnotetext{
${ }^{128}$ Derek Bryceson and Jane Goodall, "Explaining Tanzania ... Its Problems and Policies in a Renewed Commitment to Conservation," Africana 5, no. 10 (July 1975): 11-15; "The Future for Mweka ... New Parks ... and New Style Tourist Accommodation," Africana 5, no. 10 (July 1975): 16.

${ }^{129}$ Bryceson and Goodall, "Explaining Tanzania," 14.

130 "The Future for Mweka," 16.

${ }^{131}$ John Eames, editorial, Africana 5, no. 10 (July 1975): 3.

132 "The Story of the Uganda National Parks."

133 CAWM, 11th Meeting of the Governing Body, 1969, KW 4/8, KNA.

${ }^{134}$ Lamprey went on to run the Serengeti Research Institute and work for the World Wildlife Fund. Eric Pace, "Hugh Lamprey, British Pioneer of Ecology in Africa, Dies at 67," New York Times, 3 March 1996.
} 
Ford Foundation. Another instructor, G. S. Child, a British citizen, was funded by the Tanzania government. Two other British citizens were paid by the Ford Foundation and from college general funds and the Overseas Service Aid Scheme. A German citizen who served as an instructor was paid by the Federal Republic of Germany. ${ }^{135}$

Employment of these expatriates was justified by their expertise and facilitated by their links to the international conservation sphere, but their presence and the culture they brought with them was the source of some tension at the college. Kinloch identified Principal Lamprey's military experience in Palestine and Egypt ("valuable discipline training") as central to his ability to handle the task before him, but some of his pupils might have disagreed. ${ }^{136}$ Later, at the Serengeti Research Institute, Lamprey sought to create an organization independent from the Tanzanian state, only to be frustrated by National Parks director John Owen, who believed that good relations with Nyerere's government were of paramount importance for conservation and scientific research in the country. ${ }^{137}$ At least one officer had been sacked from his position as head of the Uganda National Parks specifically because of his inability to work alongside his new Ugandan superior. ${ }^{138}$ Their habits, like those of their compatriots in game and national parks departments, died hard. In 1963, the year of Kenya's independence, the country's National Parks department continued to use colonial-inspired criteria for seeking candidates for CAWM. In reviewing the candidacy of student Hassan Said, parks director Mervyn Cowie wrote that although Said "has not had a great deal of experience in dealing with tourists ... he is a very sensible man and I think has great loyalty for European officer and Europeans in general without, as far as I know, any strong political views ... [or] a 'chip on the shoulder' attitude." Another candidate, Elisha Kavaluvu, was a "stable and reliable chap," although Cowie admitted to knowing nothing of his politics. ${ }^{139}$

Some graduates felt underserved by their experience at the college or by the lack of recognition from their home governments for their training. One group wrote to the chief game warden in Kenya in 1967 to point out the unwillingness of that department to find them secure work after they finished the CAWM certificate course. The college principal in forwarding the letter exasperatedly noted that he had warned the students in question "that the matter was not worth pursuing." 140 More seriously, the year before, seventeen students had signed a protest to the principal, saying that "at this stage we are greatly fed up with a series of threats given by some Instructors both in and outside classes." Their grievances were several-fold: students resented being addressed in what they considered "the most humiliating and disrespectful language," and charged that "threats and ridicule have become the habitual weapons of certain instructors." They believed that they were deliberately made to drink unclean water, begrudged the rules that permitted instructors to bring radios on safari while

\footnotetext{
135 CAWM Newsletter, 1964, KW 4/5, KNA.

136 Kinloch, Tales from a Crowded Life, 278.

137 "Proceedings of Meeting of the Serengeti Research Society, 12-13 December 1965," SRI, F. 46, Weston Library, Oxford.

${ }^{138}$ CAWM, 1lth Meeting of the Governing Body, 1969, KW 4/8, KNA; letter, Delaney (Makerere) to Pantin, 15 February 1966, Archives of the Nuffield Unit of Tropical Animal Ecology, University Library (Cambridge).

139 Royal National Parks to Game Department, 22 May 1963, KW 4/4, KNA.

${ }^{140}$ Confidential letter, G. S. Child to chief game warden, undated [1967], KW 4/4, KNA.
} 
forbidding students to do the same, and explained that they "detest[ed] greatly the idea of forcing students to erect instructors' tents apart from erecting our own even after very long and tedious journeys to camp sites." ${ }^{\prime 41}$ Deliberately or not, this last indignity directly reconstructed the chain of command and authority structure of safaris during the colonial era, in which servants performed the major labors of setting up camp after a long day's journey while the hunter or warden rested.

Some of the former hunters and wardens staffing the college appeared unfazed by the altered environment and changed political circumstances and intended to live and work in the manner to which they were accustomed. Students argued that these practices meant that they were "robbed of [their] civil rights," and in some cases they directly compared their treatment to that meted out during the colonial era. ${ }^{142}$ They also pointed out that many of them were officers of long service and should therefore "not be treated as children in kindergarten schools." Their accounts suggest that some instructors saw the slightest expression of independence as a threat to be reflexively quashed in a manner reminiscent of colonial ideas about how to maintain authority over colonial subjects. ${ }^{143}$ The accounts also illustrate how some East African citizens took the idea of Africanization more seriously than did their governments, or at the very least had high expectations about how it should unfold and what it would mean for their interaction with state institutions and personnel.

Periodic conflict between students and college administrators and instructors continued through the 1970s. During a February 1976 trip to the Serengeti National Park, students refused to obey directions from an instructor, citing his abusive language and characterizations of Africans: "[They are] without brains to think or plan for their future but believe only in revolution." The students' demonstration resulted in the cancellation of the trip, written reprimands, temporary suspension of classes, a demand for a letter of apology from the students, the suspension of town visits, and the cancellation of a college dance. College authorities acknowledged that the instructor had addressed students in an "unpleasant manner" and denied that they did not take student grievances seriously. 144

Even the financial sponsors of the college recognized a certain institutional reluctance to turn the page on the colonial era. Support from United Nations and US organizations generally came with some form of oversight or scrutiny linked to the likelihood of receiving subsequent aid; neither did they want to be perceived as propping up the vestigial structures of empire in a Cold War context. The joint UNPD/FAO evaluation mission to Tanzania in 1969 was stinging in its evaluation of the college's failure to "fully appreciate the true nature of the fellowship system." Referring to the anticipated replacement of the externally sponsored expatriate employees, the mission noted, "At present no Tanzanians have been earmarked to take over from the UNDP staff ... the mission is extremely perturbed that there are

${ }^{141}$ Letter from students to CAWM principal, 24 February 1966, KW 4/5, KNA.

142 Ibid., KW 4/4 and 4/5, KNA.

${ }^{143}$ Ibid., 24 February 1966, KW 4/5, KNA. "To quote an example," they wrote, "the students politely requested that a vehicle be sent to fetch clean drinking water, but this immediately earned us a threat of report to the principal.”

${ }^{144}$ CAWM memo, 10 February 1976; letter from CAWM to sponsoring organizations, 20 February 1976; letter from certificate students to chairman of the CAWM board, 11 February 1976, KW 4/9, KNA. 
no FAO/UNDP Tanzanian counterparts on the teaching staff." The mission saw cultural factors as well as poor planning at work and remarked acidly on "what seems to be a psychological obstacle to the appointment of local instructors to the college staff." When the evaluating team pointed out this failure to CAWM instructors, the reply was that "adequate calibre," "wide experience and expertise," and "courage-so that when in charge of students they would not panic" were the characteristics necessary in instructors. The implication was that Africans lacked such characteristics. The report concluded, "The mission ... admits ignorance regarding the psychological requirements of a wildlife manager, but it cannot imagine how these may be presumptively recognized. The mission therefore suggests that this particular problem be resolved by recruiting qualified Tanzanians to the staff as soon as possible" (emphasis in the original). ${ }^{145}$

These disputes and their visibility to international funders illustrated the limits faced by the policy of Africanization and the vision of the college when they ran up against entrenched institutional cultures and the resilience of particular personnel and their methods. They demonstrate how, institutionally, conservation functioned at global, national, and local levels on different terms, and how the "success" of places like CAWM depended on perspective.

\section{CONCLUSION}

The college at Mweka remains a significant force in the conservation world of Africa and retains its international links. As of 2003, CAWM had trained 2,500 students, while a West African emulator had trained an additional eight hundred new conservationists. ${ }^{146}$ Other training centers emerged in Botswana, the Central African Republic, Kenya, Mozambique, Nigeria, Zambia, and Zimbabwe in the two decades after CAWM's creation, emulating the Tanzanian college. ${ }^{147}$ Allocating credit for Tanzania's pioneering college proved to be as contested as the conditions of its founding. Later in life, Bruce Kinloch resented being written out of the early history of the college. He groused over an official institutional history that was "gilded and glossed over, leaving the reader with the impression that the College of African Wildlife Management came into being in a vague form of immaculate conception, inspired by several fairy godmothers in the shape of certain international aid organizations." 148 Kinloch's complaint might have been more personal than political, but he was certainly correct in his observation that no monocausal explanation would suffice for explaining CAWM's emergence on the conservation scene. Kinloch's own account, the most consolidated existing narrative of the college, suggested that the institution owed its existence primarily to a single fairy godmother in the form of the retiring British warden. In reality, the college was given life by any

\footnotetext{
${ }^{145}$ Report of the Joint UNDP/FAO evaluation mission to Tanzania, January 1969, KW 4/8, KNA (emphasis in the original).

${ }^{146}$ Paul Scholte, "Curriculum Development at the African Regional Wildlife Colleges, with Special Reference to the Ecole de Faune, Cameroon," Environmental Conservation 30, no. 3 (September 2003): 24958 , at 249 .

${ }^{147}$ Hutagalung and Sawe, "Progress Report, 19."

${ }^{148}$ Kinloch, Shamba Raiders, 390.
} 
number of specific historical actors: the ministerial son of a game ranger; Tanzania's most celebrated nationalist leader; an assured American lawyer; a hard-nosed former Ugandan warden; officials at global foundations and conservation agencies; and students whose career aspirations and activism shaped the institution at which they learned before departing to serve not only their fledgling nations but also the global public that had invested in conservation.

Beyond those individuals, the college was the product of large-scale historical trends: efforts by internationalists to create institutions fit for a world after war; the decolonization of huge swathes of the world; the emergence of philosophies and doctrines of development; and efforts of new African nations to claim ownership over the levers of power and to negotiate more acceptable relations with former colonizers, global superpowers, and the transnational institutions of their world. The college was a product of imperially induced anxieties, a dialogic project of Africanization involving nations and empires, and a new world in which global institutions came to play the homogenizing role once envisioned for failed imperial projects.

The College of African Wildlife Management shows us that the study of imperial Britain need not always turn back to Britain in search of the cultural, social, and intellectual legacies of imperialism after the Union Jack fluttered down flagpoles and the last governors boarded flights bound for a metropole stripped of its empire. While others have directed attention to international institutions and the work of nongovernmental organizations as spaces for the continued imprint of empire or transplantation of expertise, sometimes colonial personnel remained unhidden in plain sight. ${ }^{149}$ The story of the college demonstrates that colonial officials, their ideas, and their cultures remained embedded in state institutions. CAWM's creation and its contested history show us that independent states were clear-eyed about the threats to sovereignty posed by old states and new international organizations and entered into unequal, transactional relationships with these because they believed they had the power to shape those relationships. In thinking through the end of empire, we must consider the work that states, societies, and people in former colonies did by way of seeking to co-opt, dismantle, or constrain the cultures and institutions of empire that persisted by virtue of their personnel, structure, and knowledge systems.

\footnotetext{
${ }^{149}$ Hodge, Triumph of the Expert; Tehila Sasson and James Vernon, "Practising the British Way of Famine: Technologies of Relief, 1770-1885," European Review of History-Revue europeenne d'histoire 22, no. 6 (2010): 860-72; Bailkin, Afterlife of Empire.
} 